\title{
Is women's human capital valued more by markets than by planners?
}

\author{
Daniel Münich $^{\text {a }}$, Jan Svejnar ${ }^{\mathrm{b}}$, Katherine Terrell ${ }^{\mathrm{b}, *}$ \\ ${ }^{\text {a } C E R G E-E I, ~ P o l i t i c k y c h ~ v e z n u ~ 7, ~} 11121$ Praha 1, Czech Republic \\ ${ }^{\mathrm{b}}$ Ross School of Business at the University of Michigan Business School, 701 Tappan Street, \\ Ann Arbor, MI 48109-1234, USA
}

Received 3 December 2004; revised 28 February 2005

Available online 25 April 2005

\begin{abstract}
Münich, Daniel, Svejnar, Jan, and Terrell, Katherine-Is women's human capital valued more by markets than by planners?

Using micro data on women in the Czech Republic, we compare returns to various measures of human capital at three points in time, namely, the end of Communism (1989), in mid-transition (1996), and in late-transition (2002). We find dramatic increases in returns to education from 1989 to 1996 but no change from 1996 to 2002 and no differences in returns to education in state vs. privately-owned firms. We demonstrate that sheepskin or diploma effects exist in both regimes and rise over time; moreover, they are similar across firm ownership types. We find no difference between the returns to education obtained during Communism and the returns to schooling obtained during the transition. Wage-experience profiles do not change over time. The pattern and rates of increase in the returns to education over these three points in time are similar for women and men. In sum, markets pay women and men equally more for their human capital than did the planners; all of the adjustment occurred early in the transition and it was driven by market forces rather than private ownership. Journal of Comparative Economics 33 (2) (2005) 278-299. CERGE-EI, Politickych veznu 7, 11121
\end{abstract}

In preparing the paper, the authors were supported in part by grants from the National Science Foundation (Grant No. SES 0111 783), PHARE (Grant No. CZ 9406 01-01-03), by the National Council for East European and Eurasian Studies (Contract No. 812-32) and by the US Agency for International Development (SEGIR EP Contract No. PCE-I-00-00-00014-00, Russia Task order No. 803).

* Corresponding author.

E-mail address: terrell@umich.edu (K. Terrell).

0147-5967/\$ - see front matter (C) 2005 Association for Comparative Economic Studies. Published by Elsevier Inc. All rights reserved. doi:10.1016/j.jce.2005.03.009 
Praha 1, Czech Republic; Ross School of Business at the University of Michigan Business School, 701 Tappan Street, Ann Arbor, MI 48109-1234, USA.

(c) 2005 Association for Comparative Economic Studies. Published by Elsevier Inc. All rights reserved.

JEL classification: J24; J31; P20; P31

Keywords: Human capital; Wages; Transition; Sheepskin effects; Czech Republic

\section{Introduction}

Several authors investigate whether the overall gender wage gap has increased in transition economies. ${ }^{1}$ In this paper, we examine the extent to which markets pay women more for their human capital than did the planners. In addition, we consider whether the shift to market-based wages affected the return to the human capital of men and women equally and whether the results vary with firm ownership. ${ }^{2}$ To address these issues, we use data from special surveys from the Czech Republic and estimate women's returns to education and experience at the end of the Communist period, i.e., 1989 and at both six and twelve years after the start of transition, i.e., 1996 and 2002, respectively. We compare our findings to those in Münich et al. (2005) that estimates men's returns using the same data for 1989 and 1996 and we estimate men's returns in 2002. Finally, we compare our results to those in other studies of the changes in returns to human capital for men and women in other transition economies.

In addition to increasing our understanding of gender differentials in the returns to human capital before and during the transition, our study contributes to the literature by examining returns to various measures of human capital. In particular, we examine the returns to actual years of schooling as a measure of education rather than to imputed years based on the highest degree obtained. We use the information on actual years of education and highest level attained for each individual to test for the bias from using imputed measures of schooling and to measure sheepskin effects, i.e. sharp increases in wages at the time a degree is received after controlling for years of education. We also test directly whether education obtained in the Communist period generates a different rate of return than schooling obtained during the transition period. Finally, we test whether market forces induce identical wage setting in all firms or whether rates of return on human capital differ across firm ownership. In particular, we compare the returns to human capital in the state sector with those in the private sector.

We demonstrate that the Communist system maintained an extremely low rate of return to education for women. In addition, the first six years of the transition resulted in a major increase in the rates of return to a year of education and, surprisingly, the returns remained constant in the second six years of the transition. We find no significant difference in the

\footnotetext{
${ }^{1}$ Hunt (2002), Joliffe (2002), Jurajda (2003) and Ogloblin (1999) are recent studies of the change in the gender gap in transition economies.

2 According to our data, the overall gender wage gap fell over the period under consideration. In 1989, women earned 33\% less than men, on average, and in 1996 and 2002, the differences were 29 and 25\%, respectively.
} 
returns to a year of education between the state sector and private sectors in either 1996 or 2002. With two exceptions, the same result holds for returns to the various levels of education. Hence, the major plan-to-market adjustment in rates of return to human capital occurred in the first six years of the transition.

With respect to other measures of human capital, we show that the sheepskin effect was prevalent during Communism for vocational high school and university graduates. Between 1989 and 1996, the size of the coefficients increased considerably for both of these degrees; the coefficients became statistically significant and grew for an academic high school degree. Moreover, the 1996 sheepskin effects were replicated in the 2002 data and were virtually identical across ownership types. We demonstrate why earlier studies overestimated the rates of return to education by using years of education imputed from the highest degree obtained rather than actual years of schooling as an explanatory variable. Our estimates of the effects of experience on earnings indicate that the wage-experience profile of women was concave in both regimes and, on average, it did not change from the Communist to the middle and late transition periods. We find that education obtained after the Communist period does not have higher returns than education during Communism, for both 1996 and 2002, despite the fact that several changes were made in the education system and more women had the opportunity to study in the 1990s. Finally, we show that women and men experienced virtually identical changes in the returns to their education over this period, a pattern that is also found for several other transition economies.

The paper is organized as follows. In Section 2, we describe the data and methodology. Section 3 contains the empirical findings on returns to traditional and non-traditional measures of education in 1989, 1996, and 2002. In Section 4, we examine the returns to experience in each of these three years and compare our findings on women to previous findings for men in Münich et al. (2005) and to the findings in the literature for other transition economies. Finally, in Section 5, we consider the broader implications of this work for understanding the impact of the transition to a market economy on wage setting.

\section{Data and methodology}

We use data from two surveys that employ nearly the same questionnaire and sampling frame. The first survey was administered in December 1996 to 3157 randomly selected households in all districts of the Czech Republic. The second one was administered in December 2002 to 3081 households in all districts of the Czech Republic. The second survey is not selected randomly because we attempted to follow up on as many households from the 1996 survey as possible; we succeeded in obtaining responses from 721 households, constituting 1125 individuals appearing in both surveys. The remaining households and individuals were selected in such a way as to ensure that the final sample was representative in 2002. Comparisons of the major demographic characteristics of the 1996 and 2002 
samples with the corresponding populations from the 1996 and 2002 Labor Force Survey indicate that the samples are representative. ${ }^{3}$

The questionnaire administered in December 1996 asks for the wage and other characteristics of the jobs held at the time and also in January 1989, the first month of the last year of the Communist regime. ${ }^{4}$ The questionnaire administered in December 2002 asks virtually the same questions about the job held at the time of the survey. Two important questions varied slightly. First, in 1996, a respondent could include taxes and child benefits in the earnings while, in 2002, earnings were reported as net of any tax and transfers. Hence, we include control variables for the 1989 and 1996 data to make them comparable to the 2002 data. Second, in 1996, respondents were asked whether the firm in which they worked was a state-owned enterprise (SOE), a privatized SOE or a new (de novo) private firm. In 2002, participants were asked only if the firm was privately owned. In order to make this variable comparable over time, we combine the firm size and ownership categories to create a new variable in 2002, namely, large private firms with more than 50 employees vs. small private firms with less than 50 employees. In 1996, most of the privatized firms had more than 50 employees and most of the de novo firms had less than 50 employees so that these categories are similar. The comparable data permit us to estimate cross-sectional earnings functions at one point in time near the end of Communism, i.e., January 1989, one point in time in the middle of the transition, i.e., December 1996, and one point late in the transition, i.e., December 2002.

One potential weakness of the 1989 retrospective data is the possibility of recall error. In our case, the problem is that individuals may not remember accurately their past wages. However, we expect this error to be relatively small because wages set in the Communist grid were clearly defined and did not change much over time and also because January 1989 was a memorable period that people could recall quite clearly in $1996 .^{5}$ Moreover, we use the self-reported wage as a dependent variable rather than as a regressor so that we avoid the usual problem of errors-in-variables bias with respect to the right-hand-side variables.

To obtain estimates of the returns to human capital at the end of Communism and during the transition, we estimate the following human capital earnings function with our 1989 and 1996 cross-sectional data:

$$
\ln W_{i}=\alpha_{0}+\alpha_{1} E_{i}+\alpha_{2} X_{i}+\alpha_{3} X_{i}^{2}+\alpha_{4} P_{i}+A_{i}^{\prime} \beta+\varepsilon_{i},
$$

where $\ln W_{i}$, the natural logarithm of the hourly earnings of individual $i$, is taken to be a function of educational attainment $\left(E_{i}\right)$, number of years of potential labor market experience $\left(X_{i}\right)$, a dummy variable for whether the individual worked in Prague $\left(P_{i}\right)$, and a set of

\footnotetext{
3 Münich et al. (1997) and MEDIAN (2003) provide a description of the survey and the sample design as well as the descriptive statistics of the sample relative to the Labor Force Survey (Czech Statistical Office, 1996) and microcensus (Czech Statistical Office, 2002) data.

4 The January 1989 date was selected as a point in time at which people were likely to remember their labor market characteristics because 1989 was the year of the revolution that overthrew the Communist regime.

5 Münich et al. (2005) provide evidence on the Communist wage grid.
} 
ten industry dummy variables for the industry of the individual's job $\left(A_{i}\right){ }^{6}$ The variables $A$ and $P$ control for industry wage effects, compensating differentials, and agglomeration effects of the central city.

In addition to examining the returns to all female workers, we compare the returns to human capital in the state sector, which includes state-owned enterprises, public administration, health and education, and in the private sector. In 1996, we subdivide the private sector into privatized firms and de novo private firms because of the interest in the literature in this distinction in the early part of transition. However, in 2002, we no longer have information on whether a firm is a new private firm so that we divide private firms into small and large ones, using 50 employees as the threshold.

An important stylized fact from the human capital literature is that the effect of education on wages often depends on how the education variable is measured. Unlike Krueger and Pischke (1995), Chase (1998) and Flanagan (1998), who must impute this variable from the highest educational degree completed, we are able to test the relative merit of three different specifications. We have data on the actual self-reported number of years of education, net of grade repetition, and the highest level of schooling attained. We use each separately and then combine them.

The specification based on the number of years of education yields an estimate of a constant marginal rate of return for an additional year of schooling and follows the approach advocated by Layard and Psacharopoulos (1974). Using the highest level of educational attainment by type of degree obtained allows the rate of return to vary across types of completed education and responds to the criticism of the assumption of a constant rate of return to each year of education from Heckman et al. (1996). ${ }^{7}$ By including both of these variables, we test the competing specifications to see which is better supported by the data in the Communist period and during the transition. Moreover, we have data on the actual years of schooling reported by the respondent, rather than years imputed by the researchers from the reported school attainment. Hence, we can test the sheepskin hypothesis that wages rise faster with extra years of education when the extra year also conveys a certificate. $^{8}$

\footnotetext{
6 The questionnaire asks about monthly nominal earnings and the number of hours worked per week. Hence, we have calculated the hourly earnings based on 8.5 hour work-days, which was common in this period. Although Czechs tend to recall their salary net of payroll and income taxes because both of these taxes are taken out before they receive their pay in 1989 and 1996, about 25 percent of the respondents reported their gross rather than net earnings. As a result, we included a dummy variable to control for this discrepancy in reporting. In addition, in 1989 and 1996, net earnings include benefits provided by the state, through the employer, for raising children in some cases. Therefore, we also included a dummy variable for those two years to control for the cases in which the reported earnings included child benefits. In 2002, these respondents were asked explicitly to report earnings net of taxes and child benefits.

7 Our data permit us to estimate a specification with six categorical variables reflecting the highest degree attained. These are junior high school due to mandatory education of 9 years, apprentices in two to three-year programs, technical high school graduates and apprentices in four-year programs who received the technical high school diploma, academic high school graduates, and university graduates and above.

8 The sheepskin effect refers to the fact that wages may not increase steadily with years of education within a given level of schooling but rather rise dramatically when a degree is received as Heckman et al. (1996) assert. Using US data, Hungerford and Solon (1987) find significant discrete jumps in the return to education upon receiving a degree.
} 
The potential labor force experience variable is calculated in the usual way by taking the individual's age minus the sum of the individual's years of schooling plus a basic school enrollment age of six years. However, given the standard practice in the Czech Republic that women take three years of maternity leave, we also use a second measure to adjust a woman's potential experience by subtracting three years for each of her children.

A common concern when estimating earnings functions is self-selection, i.e., the potential for censoring either at the top or the bottom of the wage distribution if some people choose not to work so that their earnings are not observable. A two-step procedure suggested by Heckman (1974) has been used widely to correct for selectivity bias when estimating women's earnings functions. However, Nawata (1993) and Puhani (2000) criticize this method on several grounds. First, the two-step estimators are overly sensitive to distributional assumptions imposed on the error term in both equations. If the error in the selection equation is not normally distributed, the two-step linear formula does not apply and the estimators are biased. Second, the second-stage earnings equation estimates are often subject to multicollinearity, which has an adverse impact on robustness of the two-step estimator. In particular, multicollinearity becomes a problem if the explanatory variables are highly correlated with the inverse Mills ratio. In applications like ours in which the set of variables in the selection and earning equations overlap significantly and the excluded identifying set of variables is not a strong predictor of participation, this problem is common. Given that we do not have variables that predict participation strongly but not earnings, we do not correct for potential selectivity bias. ${ }^{9}$ Hence, our estimates should be interpreted as returns to human capital, conditional on participation in the labor market.

In Appendix Table A.1, we present the means and standard deviations of the variables that we use in estimating the earnings functions. For full-time working women, between the ages of 15 and 60, we have useable data on 1642 individuals in 1989, 1374 in 1996, and 1104 in $2002 .{ }^{10}$ As the table indicates, the average log nominal earnings rises substantially over the period, from 7.9 to 8.7 to 9.1 . The average number years of education remains fairly constant at around 12 years and about two-thirds of the working women attained a vocational or academic high school degree. Over time, the share of women with only a junior high school education falls while the share with academic high school rises. The average number of years of experience in the labor market rises from 17 under Communism to about 20 during the transition.

The structure of jobs in the Czech economy changed in ways that are common to most transition economies. The shares of employment in agriculture and manufacturing fell, while the shares in commerce or trade and financial services increased rapidly. The struc-

\footnotetext{
9 Additional factors played a role in our decision not to estimate the Heckman's two-step procedure. First, we do not see a large change in women's participation rates from 1993 to 2002 in either our data or in the Labor Force Survey data, which reports female labor force participation rates (LFPRs) of 52.3 in 1993, 51.8 in 1996 , 52.1 in 1999, 51.3 in 2001 and 50.9 in 2002. Moreover, the structure of education of women did not change in our sample. Second, we do not have the necessary information on education for women who were not in the labor force in any year and, in 1989, we do not have information on household characteristics, marital status, and other characteristics of the women who were not in the labor force.

10 During this period, women in the Czech Republic had a very low incidence of part-time work.
} 
ture of jobs by ownership of firms changed dramatically from virtually complete state ownership in 1989 to only $25 \%$ in 1996 . However, there was little change in the structure of jobs by type of firm ownership between 1996 and 2002, with the caveat that the two private ownership categories are not strictly comparable across the two surveys. The descriptive statistics indicate that, by 1996, the economy appears to have reached a steady state in which about one third of the jobs are in large private firms, one third in small private firms, about one quarter in the public sector (SOE or public administration), and the remainder in a residual category not specified by respondents.

\section{Traditional and non-traditional estimates of returns to education}

In Table 1, we present the most commonly reported estimates of returns to education, namely, returns to a year of education in panel A and returns to various levels of educational attainment in panel B. These estimates come from two separate regressions and control for the variables listed in Eq. (1). Clearly, markets are paying women considerably more than did the planners for an additional year of education but, interestingly, all the adjustment was made in the first six years of the transition. The returns to a year of schooling rose significantly from 3.7 percent in 1989 to 7.1 percent in 1996 but then did not change significantly in 2002. ${ }^{11}$ The 1996 and 2002 rates of return are very similar to

Table 1

Estimated returns to a year of education and to a level of education for all women, 1989, 1996 and 2002

\begin{tabular}{|c|c|c|c|}
\hline Variable & 1989 & 1996 & 2002 \\
\hline \multicolumn{4}{|l|}{ Panel A } \\
\hline Year of education & $\begin{array}{l}0.039^{* * *} \\
(0.004)\end{array}$ & $\begin{array}{l}0.071^{* * *} \\
(0.005)\end{array}$ & $\begin{array}{l}0.068^{* * *} \\
(0.005)\end{array}$ \\
\hline \multicolumn{4}{|c|}{ Panel B. Level of attainment (base is junior high school) } \\
\hline Apprentices & $\begin{array}{l}0.066^{* *} \\
(0.029)\end{array}$ & $\begin{array}{l}0.156^{* * *} \\
(0.027)\end{array}$ & $\begin{array}{l}0.124^{\text {**** }} \\
(0.029)\end{array}$ \\
\hline Vocational h.s. (4 years) & $\begin{array}{l}0.197^{\text {**** }} \\
(0.029)\end{array}$ & $\begin{array}{l}0.384^{* * *} \\
(0.028)\end{array}$ & $\begin{array}{l}0.315^{\text {*** }} \\
(0.030)\end{array}$ \\
\hline Academic h.s. (4 years) & $\begin{array}{l}0.103^{* *} \\
(0.042)\end{array}$ & $\begin{array}{l}0.368^{* * *} \\
(0.040)\end{array}$ & $\begin{array}{l}0.359^{* * *} \\
(0.037)\end{array}$ \\
\hline University & $\begin{array}{l}0.365^{\text {*** }} \\
(0.040)\end{array}$ & $\begin{array}{l}0.645^{\text {**** }} \\
(0.040)\end{array}$ & $\begin{array}{l}0.610^{* * *} \\
(0.040)\end{array}$ \\
\hline
\end{tabular}

Notes: (i) Standard errors are in parentheses. (ii) The coefficients are estimated from separate regressions for years vs. levels. (iii) All regressions include experience, experience ${ }^{2}$, and dummies controlling for region of work (Prague) and industry of job (one-digit level). The 1989 and 1996 regressions also include dummies for inclusion of child allowances or taxes in wages, and industry of job (one-digit level).

** Significance at the $5 \%$ level.

*** Idem., $1 \%$.

11 The $P$-values for the $F$-tests for the coefficients on a year of education in 1989 vs. 1996 is 0.000 and for 1996 vs. 2002 it is 0.67 . 
those reported for all workers for the late 1980s in both Great Britain (6.8) and Switzerland (7.9), but somewhat less than the 9.3 percent found for the USA by Psacharopoulos (1994). ${ }^{12}$

In panel B of Table 1, we find that markets also pay women significantly more for each level of educational attainment. Again, virtually all of the increase occurs in the first six years of the transition because almost all of the 2002 coefficients are not significantly different from their 1996 counterpoints. The exception is the return to vocational high school education, which falls somewhat between 1996 and 2002. As an example of the considerable gains in the returns on higher education, in 1989, a university education yielded earnings that were $36.5 \mathrm{log}$ points or $45 \%$ higher than the earnings from a junior high school education but, by 1996 and 2002, university graduates were receiving nearly double the earnings of the junior-high graduates.

To test whether this funding is driven by markets or by private ownership, we compare returns across enterprises having different ownership types. In Table 2, we present returns to a year and a level of education for women with a job in the state sector or in one of two private-sector categories. Indeed, markets are determining returns to education throughout the economy as we find no significant differences in the returns paid between nearly all

Table 2

Estimated returns to a year and a level of education by ownership type in 1996 and 2002

\begin{tabular}{|c|c|c|c|c|c|c|}
\hline \multirow[t]{2}{*}{ Variable } & \multicolumn{3}{|c|}{1996} & \multicolumn{3}{|c|}{2002} \\
\hline & State & Privatized & De novo & State & Large private & Small private \\
\hline Year of education & $\begin{array}{l}0.063^{* * *} \\
(0.006)\end{array}$ & $\begin{array}{l}0.072^{* * *} \\
(0.013)\end{array}$ & $\begin{array}{l}0.081^{\text {*** }} \\
(0.009)\end{array}$ & $\begin{array}{l}0.068^{* * *} \\
(0.006)\end{array}$ & $\begin{array}{l}0.070^{* * *} \\
(0.011)\end{array}$ & $\begin{array}{l}0.065^{* * *} \\
(0.009)\end{array}$ \\
\hline \multicolumn{7}{|c|}{ Level of attainment (base is junior high school) } \\
\hline Apprentices & $\begin{array}{l}0.196^{* * *} \\
(0.057)\end{array}$ & $\begin{array}{c}0.080^{*} \\
(0.046)\end{array}$ & $\begin{array}{l}0.204^{* * *} \\
(0.047)\end{array}$ & $\begin{array}{l}0.206^{* * *} \\
(0.048)\end{array}$ & $\begin{array}{c}0.066 \\
(0.048)\end{array}$ & $\begin{array}{l}0.184^{\text {*** }} \\
(0.064)\end{array}$ \\
\hline Vocational h.s. (4 years) & $\begin{array}{l}0.457^{\text {*** }} \\
(0.049)\end{array}$ & $\begin{array}{l}0.320^{* * *} \\
(0.054)\end{array}$ & $\begin{array}{l}0.394^{* * *} \\
(0.050)\end{array}$ & $\begin{array}{l}0.425^{* * *} \\
(0.044)\end{array}$ & $\begin{array}{l}0.242^{* * * *} \\
(0.052)\end{array}$ & $\begin{array}{l}0.245^{\text {*** }} \\
(0.069)\end{array}$ \\
\hline Academic h.s. (4 years) & $\begin{array}{l}0.352^{\text {*** }} \\
(0.070)\end{array}$ & $\begin{array}{l}0.413^{* * *} \\
(0.078)\end{array}$ & $\begin{array}{l}0.341^{\text {*** }} \\
(0.066)\end{array}$ & $\begin{array}{l}0.388^{* * *} \\
(0.051)\end{array}$ & $\begin{array}{l}0.297^{\text {*** }} \\
(0.070)\end{array}$ & $\begin{array}{l}0.369^{* * *} \\
(0.077)\end{array}$ \\
\hline University & $\begin{array}{l}0.616^{\text {*** }} \\
(0.055)\end{array}$ & $\begin{array}{l}0.801^{* * *} \\
(0.118)\end{array}$ & $\begin{array}{l}0.781^{\text {*** }} \\
(0.089)\end{array}$ & $\begin{array}{l}0.649^{* * * *} \\
(0.052)\end{array}$ & $\begin{array}{l}0.703^{* * *} \\
(0.089)\end{array}$ & $\begin{array}{l}0.610^{* * *} \\
(0.087)\end{array}$ \\
\hline
\end{tabular}

Notes: (i) Standard errors are in parentheses. (ii) The estimates are based on separate regressions for years vs. levels and for each ownership type. (iii) All regressions include the additional variables described in Eq. (1) and in note (iii) of Table 1.

* Significance at the $10 \%$ level.

*** Idem., $1 \%$.

\footnotetext{
12 Psacharopoulos (1994) estimates returns to education for men and women around the world and finds that women tend to have higher returns to education than men. In the Czech Republic, the estimated returns for men using the same data were 2.7, 5.8 and 5.7 in 1989, 1996, and 2002, respectively. Hence, the Czech results are consistent with those in other countries.
} 
pairs of these three ownership types. ${ }^{13}$ The one exception is the return to vocational education, for which the state sector pays more relative both to privatized firms in 1996 and to large private firms in 2002. In addition, Table 2 indicates that the returns to either a year or a level of education did not change between 1996 and 2002 for any of three sectors, with the one exception being the falling return to vocational schooling in small private de novo firms. ${ }^{14}$

Screening theories of education suggest that diplomas serve as a signal of higher productivity so that diplomas or sheepskins should be rewarded in the labor market. The usual test for sheepskin effects is to estimate the difference in wages of individuals with and without a diploma, conditional on the number of years of schooling. Except for Jaeger and Page (1996), numerous studies using US data to test for sheepskin effects, e.g., Hungerford and Solon (1987) and Card and Krueger (1992), are based on data that do not have information on the highest degree attained by an individual. Therefore, these authors must impute the level attained from the usual number of years it takes to complete a given degree. In contrast, researchers of transition economies often have information only on the highest degree attained and must impute the number of years of schooling of an individual by using the usual number of years it takes to complete a degree. To the extent that individuals obtain a diploma with more or fewer years of study, estimates of sheepskin effects in the US and returns to a year of education in the transition countries are biased. We have information on both the individual's reported years of education, net of any repeated grades, and the highest degree attained. Hence, we can obtain unbiased estimates of the sheepskin effect and also test for the bias from using imputed vs. actual years of schooling. We develop a new way of testing for the sheepskin effect by estimating returns to years of study that lead to a degree compared with those that do not.

In Table 3, we present the coefficients for a regression that includes years of education, net of grade repetition, and dummy variables for the highest degree attained, estimated from the 1989, 1996, and 2002 cross-sectional data and controlling for the variables listed in Eq. (1). Sheepskin effects are not nearly as prevalent under Communism as they are in the market-based system because the Communists valued only vocational high school and university diplomas whereas markets value all four diplomas. Market effects were established by 1996 and $F$-tests on pair-wise differences of the coefficients indicate that the value of these three degrees did not grow significantly between 1996 and 2002. Table 4 presents our analysis of the sheepskin effect by firm ownership during the transition. All three types of firms value degrees and, for the most part, they do not differ in their valuation

\footnotetext{
13 The $P$-values for the tests on the difference in the coefficients on a year of education are in the following table:
}

\begin{tabular}{lcc}
\hline Ownership & 1996 & 2002 \\
\hline State vs. privatized or large private & 0.530 & 0.875 \\
Privatized/large private vs. de novo/small private & 0.569 & 0.725 \\
De novo/small vs. state & 0.110 & 0.786 \\
\hline
\end{tabular}

14 The $P$-values for the $F$-tests comparing the 1996 vs. 2002 coefficients on a year of education for the state sector is 0.570 , for privatized/large private, it is 0.961 and, for de novo/small private, it is 0.209 . 
Table 3

Sheepskin effects for all women, 1989, 1996 and 2002

\begin{tabular}{lccc}
\hline Variable & 1989 & 1996 & 2002 \\
\hline Year of education & 0.006 & $0.024^{* * *}$ & $0.021^{*}$ \\
Apprentices & $(0.009)$ & $(0.008)$ & $(0.011)$ \\
& 0.039 & $0.091^{* * *}$ & $0.070^{*}$ \\
Vocational h.s. (4 years) & $(0.036)$ & $(0.033)$ & $(0.041)$ \\
& $0.165^{* * *}$ & $0.286^{* * *}$ & $0.237^{* * *}$ \\
Academic h.s. (4 years) & $(0.046)$ & $(0.044)$ & $(0.05)^{* * *}$ \\
& 0.076 & $0.229^{* * *}$ & $0.284^{* * *}$ \\
University & $(0.054)$ & $(0.050)$ & $(0.055)$ \\
& $0.320^{* * *}$ & $0.451^{* * *}$ & $0.444^{* * *}$ \\
\hline
\end{tabular}

Notes: (i) Standard errors are in parentheses. (ii) Each column represents a separate regression that includes the same control variables as in note (iii) of Table 1.

* Significance at the $10 \%$ level.

*** Idem., $1 \%$.

Table 4

Sheepskin effects by ownership type, 1996 and 2002

\begin{tabular}{|c|c|c|c|c|c|c|}
\hline \multirow[t]{2}{*}{ Variable } & \multicolumn{3}{|c|}{1996} & \multicolumn{3}{|c|}{2002} \\
\hline & State & Privatized & De novo & State & Large private & Small private \\
\hline \multirow[t]{2}{*}{ Year of education } & $0.020^{*}$ & -0.012 & $0.037^{* * *}$ & $0.036^{* * *}$ & 0.018 & 0.004 \\
\hline & $(0.011)$ & $(0.017)$ & $(0.014)$ & $(0.013)$ & $(0.024)$ & $(0.020)$ \\
\hline \multirow[t]{2}{*}{ Apprentices } & $0.145^{* *}$ & $0.112^{*}$ & $0.098^{*}$ & $0.118^{* *}$ & 0.016 & 0.074 \\
\hline & $(0.063)$ & $(0.065)$ & $(0.058)$ & $(0.058)$ & $(0.085)$ & $(0.083)$ \\
\hline \multirow[t]{2}{*}{ Vocational h.s. (4 years) } & $0.376^{* * *}$ & $0.367^{* * *}$ & $0.232^{* * *}$ & $0.290^{* * *}$ & 0.170 & $0.230^{* *}$ \\
\hline & $(0.068)$ & $(0.085)$ & $(0.083)$ & $(0.069)$ & $(0.108)$ & $(0.104)$ \\
\hline \multirow[t]{2}{*}{ Academic h.s. (4 years) } & $0.278^{* * *}$ & $0.456^{* * *}$ & $0.201^{* *}$ & $0.260^{* * *}$ & $0.225^{*}$ & $0.355^{* * *}$ \\
\hline & $(0.081)$ & $(0.094)$ & $(0.087)$ & $(0.072)$ & $(0.121)$ & $(0.106)$ \\
\hline \multirow[t]{2}{*}{ University } & $0.459^{* * *}$ & $0.899^{* * *}$ & $0.470^{* * *}$ & $0.361^{* * *}$ & $0.561^{* * *}$ & $0.575^{* * *}$ \\
\hline & $(0.104)$ & $(0.180)$ & $(0.149)$ & $(0.118)$ & $(0.200)$ & $(0.191)$ \\
\hline
\end{tabular}

Notes: (i) Standard errors are in parentheses. (ii) Each column represents a separate regression that includes the same control variables as in note (iii) of Table 1.

* Significance at the $10 \%$ level.

** Idem., $5 \%$.

*** Idem., $1 \%$.

of degrees within a given year. The exception is the privatized sector's higher valuation of academic high school and university degrees in 1996, which most likely reflects a temporary foreign language premium. ${ }^{15}$

We take advantage of the dual reporting in our data and re-estimate our regressions with the imputed years of education to assess the magnitude of the bias of this commonly used measure. Normally, the imputed years of education is expected to generate a downward

$15 F$-tests of all other pair-wise comparisons indicate that the differences are not significantly different from zero at the $10 \%$ confidence level. 
Table 5

Estimated returns for imputed years of education and additional years of schooling, 1989, 1996 and 2002

\begin{tabular}{|c|c|c|c|c|c|c|}
\hline \multirow[t]{2}{*}{ Variable } & \multicolumn{2}{|c|}{1989} & \multicolumn{2}{|c|}{1996} & \multicolumn{2}{|c|}{2002} \\
\hline & (1) & (2) & (3) & (4) & (5) & (6) \\
\hline Imputed years of education & $\begin{array}{l}0.044^{* * *} \\
(0.004)\end{array}$ & $\begin{array}{l}0.044^{* * * *} \\
(0.004)\end{array}$ & $\begin{array}{l}0.074^{* * *} \\
(0.005)\end{array}$ & $\begin{array}{l}0.074^{* * * *} \\
(0.004)\end{array}$ & $\begin{array}{l}0.085^{* * *} \\
(0.005)\end{array}$ & $\begin{array}{l}0.085^{\text {*** }} \\
(0.005)\end{array}$ \\
\hline Additional years & - & $\begin{array}{c}0.025^{* *} \\
(0.011)\end{array}$ & & $\begin{array}{l}0.026^{* * *} \\
(0.011)\end{array}$ & - & $\begin{array}{c}0.013 \\
(0.011)\end{array}$ \\
\hline
\end{tabular}

Notes: (i) Standard errors are in parentheses. (ii) Imputed years denote the number of years of education imputed from the individual's highest level of educational attainment and the usual number of years it takes to attain that level/degree. (iii) Additional years denote the number of years above the highest level of attainment that do not lead to a degree. (iv) Each column represents a separate regression that includes the same control variables as in note (iii) of Table 1.

** Significance at the $5 \%$ level.

*** Idem., $1 \%$.

bias due to errors in variables. However, the imputed years of education may generate an upward bias if the measure underestimates systematically the number of years of schooling for people that study for additional years without obtaining a degree. We find that the coefficients on imputed years of schooling in columns (1) and (5) are lightly higher than the coefficients on actual years attended in Table 1 for 1989 and 2002. However, the difference is statistically significant only in 2002. The $F$-test does not allow us to reject the hypothesis that the coefficients on an imputed vs. a reported year of education are not statistically different from one another in 1989 and $1996 .^{16}$

We also test the hypothesis that a year of education that leads to a degree has a higher payoff than a year that does not result in a degree. To implement the test, we use our information on the total number of reported years of education and the highest degree obtained together with the knowledge of the usual number of years needed to obtain a given degree. We impute the number of years of education both for obtaining the most advanced degree and for additional study not resulting in a degree. In columns 2, 4, and 6 of Table 5, we report the coefficients from a specification that enters these two measures as explanatory variables in regression Eq. (1). In 1989 and 1996, the coefficients on the additional years of study are significantly different from zero but smaller than the coefficients on the imputed years leading to a degree. In 2002, this coefficient is not significantly different from zero, in part because fewer women had studied beyond a degree in that year. These results confirm higher returns to a year of study that contributes toward a degree. In addition, they suggest that studies imputing years of education from educational attainment and not controlling for the drop-out or repeater phenomena overestimate the rate of return on education.

Human capital, both education and work experience, acquired under Communism is often considered to be less appropriate for a market economy than human capital acquired during the transition. Some labor economists have noted that apprenticeship and vocational education in the Communist economies were often very narrow and expressed doubt about their value in post-Communist labor markets. To test the hypothesis that education acquired

16 The $P$-values for the $F$-tests are 0.39 in $1989,0.62$ for 1996 , and 0.01 in 2002. 
Table 6

Returns to a communist vs. post-Communist education (years) in 1996 and 2002

\begin{tabular}{|c|c|c|c|c|c|c|c|c|}
\hline \multirow{2}{*}{$\begin{array}{l}\text { Years of } \\
\text { education }\end{array}$} & \multicolumn{4}{|c|}{1996} & \multicolumn{4}{|c|}{2002} \\
\hline & $\begin{array}{l}\text { All } \\
(1)\end{array}$ & $\begin{array}{l}\text { State } \\
(2)\end{array}$ & $\begin{array}{l}\text { Privatized } \\
\text { (3) }\end{array}$ & $\begin{array}{l}\text { De novo } \\
\text { (4) }\end{array}$ & $\begin{array}{l}\text { All } \\
(5)\end{array}$ & $\begin{array}{l}\text { State } \\
(6)\end{array}$ & $\begin{array}{l}\text { Large private } \\
\text { (7) }\end{array}$ & $\begin{array}{l}\text { Small private } \\
\text { (8) }\end{array}$ \\
\hline Before & $0.071^{* * * *}$ & $0.064^{* * *}$ & $0.074^{* * *}$ & $0.081^{* * * *}$ & $0.070^{* * *}$ & $0.069^{* * *}$ & $0.071^{* * * *}$ & $0.068^{* * *}$ \\
\hline 1991 & $(0.005)$ & $(0.006)$ & $(0.013)$ & (0.009) & $(0.005)$ & $(0.006)$ & $(0.001)$ & $(0.009)$ \\
\hline After & $0.061^{\text {*** }}$ & $0.050^{* * *}$ & 0.030 & $0.088^{* * * *}$ & $0.054^{* * *}$ & $0.050^{* * * *}$ & $0.060^{* * *}$ & $0.054^{* * *}$ \\
\hline 1991 & $(0.010)$ & $(0.014)$ & $(0.027)$ & $(0.020)$ & $(0.009)$ & $(0.011)$ & $(0.017)$ & $(0.016)$ \\
\hline
\end{tabular}

Notes: (i) Standard errors are in parentheses. (ii) Each column represents a separate regression that includes the same control variables as in note (iii) of Table 1.

*** Significance at the $1 \%$ level.

during the transition has a higher value than the education obtained under Communism, we identify the number of years of education obtained under Communism, i.e., before 1991, and during the transition, i.e., after 1991, for each woman. We enter these variables as separate regressors and test for differences in the returns to each type of human capital in 1996 and 2002. Our hypothesis is that the differences in the two sets of returns should be greater in 2002 because more changes had been enacted in the education system and more women have had time to participate in the new educational system by this year. ${ }^{17}$ Counter to our expectations, the estimated coefficients for all workers, presented in columns one and five of Table 6 , are actually somewhat lower for post-Communist education in both years. However, a $\chi^{2}$ test indicates that these coefficients are not significantly different from each other. Further examination of the coefficients on Communist and post-Communist education for those working in the state or either of the two private sectors in columns 2 to 4 and 6 to 8 confirms this finding of no statistically significant difference in the returns to type of education. Moreover, these returns do not change over time, either for all women, or for those in the state sector.

\section{Returns to experience and comparisons}

To estimate the returns to experience under the two regimes, we use two different measures for experience. The traditional measure takes the number of years since leaving school, which equals age minus number of years of schooling minus six. We compute an alternative measure that reflects the fact that most Czech women take three years of maternity leave when they have a child. For this measure, we subtract an additional three years for each child. However, we can make this correction only for 1996 and 2002 because in 1989 we do not know the number of children a woman had at that time. We recognize

17 Few people who obtained education under Communism re-entered schools during the transition. 
Table 7

Returns to a year of labor market experience (two measures)

\begin{tabular}{lcccccc}
\hline & \multicolumn{3}{c}{ Traditional measure } & & \multicolumn{2}{c}{ Including maternity leave } \\
\cline { 2 - 4 } \cline { 6 - 7 } & 1989 & 1996 & & 2002 & 1996 & 2002 \\
\hline Experience & $0.014^{* * *}$ & $0.009^{*}$ & $0.011^{* * *}$ & & $0.013^{* * *}$ & $0.016^{* * *}$ \\
& $(0.003)$ & $(0.005)$ & $(0.003)$ & & $(0.003)$ & $(0.004)$ \\
Experience $^{2}$ & $-0.0002^{* *}$ & -0.0001 & $-0.0002^{* * *}$ & & $-0.0002^{* *}$ & $-0.0004^{* * *}$ \\
& $(0.0001)$ & $(0.0001)$ & $(0.0001)$ & & $(0.0001)$ & $(0.0001)$ \\
\hline
\end{tabular}

Notes: (i) Standard errors are in parentheses. (ii) Each column represents a separate regression that includes the same control variables described in note (iii) of Table 1, in addition to years of education. (iii) The traditional measure of experience refers to the measure of potential experience $=$ age - years of schooling -6 ; the measuring including maternity leave subtracts an additional 3 years for each child the woman bore.

* Significance at the $10 \%$ level.

** Idem., $5 \%$.

*** Idem., $1 \%$.

that this second measure is only a rough approximation of the time that women take off for maternity leave and that it may overestimate the time for some women. ${ }^{18}$

Table 7 presents coefficients with standard errors for both the traditional measure and the correction for children in the relevant years. ${ }^{19}$ The traditional measure indicates no change over time. A woman with 10 years of experience earns approximately 0.08 to 0.12 $\log$ points, or 8.3 to $12.7 \%$, more than a woman entering the labor market for the first time, while a woman with 20 years of experience earns approximately 0.14 to $0.20 \mathrm{log}$ points, or 15.0 to $22.1 \%$, more than a woman with no experience. After adjusting for maternity leave, the profiles are steeper as expected due to the reduction in the number of years of experience. However, the $F$-tests indicate that the profiles estimated with these two different measures of experience are not significantly different from each other nor are the 1996 and 2002 profiles significantly different from each other.

Our estimates of the wage-experience profile by categories of firm ownership reported in Table 8 use only the traditional experience measure. No marked differences in experience-based wage setting by state firms and by de novo small private firms are found in either 1996 or 2002. The privatized firms in 1996 and large private firms in 2002 display statistically insignificant coefficients, suggesting that the wage-experience profile is horizontal. However, the large standard errors of these estimates do not permit us to reject the hypothesis that the coefficients are not statistically different from those in the other ownership categories.

In addition to examining the evolution of returns to women's human capital, we investigate whether markets pay higher returns for men or for women. Münich et al. (2005)

\footnotetext{
18 For example, a woman who had two children two years apart would not necessarily take six years out of the labor force to care for her children.

19 The results are based on a regression in which education is measured as actual years of schooling. We also estimated traditional experience coefficients in a regression with education measured as level of attainment and found no statistically significant difference in the traditional experience-earnings profiles estimated with years vs. attainment.
} 
Table 8

Returns to a year of labor market experience by ownership type, 1996 and 2002

\begin{tabular}{|c|c|c|c|c|c|c|}
\hline & \multicolumn{3}{|c|}{1996} & \multicolumn{3}{|c|}{2002} \\
\hline & State & Privatized & De novo & State & Large private & Small private \\
\hline Experience & $\begin{array}{c}0.009^{*} \\
(0.005)\end{array}$ & $\begin{array}{c}0.010 \\
(0.007)\end{array}$ & $\begin{array}{l}0.011^{\text {** }} \\
(0.005)\end{array}$ & $\begin{array}{l}0.017^{* * * *} \\
(0.004)\end{array}$ & $\begin{array}{c}0.002 \\
(0.005)\end{array}$ & $\begin{array}{c}0.012^{*} \\
(0.005)\end{array}$ \\
\hline Experience $^{2}$ & $\begin{array}{c}-0.0004^{* * * *} \\
(0.0001)\end{array}$ & $\begin{array}{c}-0.0001 \\
(0.0002)\end{array}$ & $\begin{array}{c}-0.0002 \\
(0.0002)\end{array}$ & $\begin{array}{c}-0.0003^{* * *} \\
(0.0001)\end{array}$ & $\begin{array}{c}-0.0001 \\
(0.0001)\end{array}$ & $\begin{array}{c}-0.0003^{* * *} \\
(0.0001)\end{array}$ \\
\hline
\end{tabular}

Notes: (i) Standard errors are in parentheses. (ii) Each column represents a separate regression that includes the same control variables as in note (iii) of Table 1 with years of education added. (iii) Experience is measured in the traditional way without any allowance for maternity leave.

* Significance at the $10 \%$ level.

** Idem., $5 \%$.

*** Idem., $1 \%$.

estimate coefficients on the years and levels of education for Czech men using 1989 and 1996 data that are derived from the same survey that we use here for women. To make a comparison by gender, we use the coefficients from Münich et al. and supplement them with estimated coefficients from Eq. (1), using the new 2002 data for men. These coefficients are reported in Appendix Table A.2, which also shows the differences in the returns to education over the 1989 to 1996 and 1996 to 2002 periods. We calculate and present the same differences for women in Appendix Table A.3. To provide a broader perspective, we also include the returns to education for men and women estimated from earlier studies of transition economies in Appendix Tables A.2 and A.3. In Table 9, we calculate the difference-in-differences and test whether the female-male differences vary significantly over time in the Czech Republic and in other transition economies.

From analyzing our Czech data, we cannot reject the hypothesis that the rates of change of returns to a year or a level of education are the same for both genders. This finding holds under Communism, in the early to-mid transition experience, and into the late transition. The first six rows of Table 9 indicate that men also experience a significant increase in the return to their education, measured in both year and levels, in the first transition period and no significant change in the coefficients in the second transition period. The gains for men and women appear to have been similar in the first transition period in the Czech Republic.

Regarding the findings in the literature, a similar pattern emerges for the relative gains of men and women in Estonia, Hungary, Poland, and Slovenia. In these countries, the returns to education rose at approximately the same rate for men and women. In particular, we detect no difference in the evolution of returns at all education levels in Estonia from 1989 to 1994, in Slovenia from 1987 to 1992, in Hungary, with the exception of college-educated women, from 1995 to 1998, and in Poland, with the exception of secondary-vocational education for women, from 1994 to $2001 .^{20}$ Although we cannot calculate statistical significance of the estimates by Brainerd (2000) for the early transition period in four countries,

\footnotetext{
20 Information for Estonia and Slovenia comes from Orazem and Vodopivec (1997). The study by Joliffe and Campos (2005) contains the information for Hungary. Adamchik and Bedi (2003) report the results for Poland.
} 
Table 9

Empirical findings on changes in women's and men's returns to education

\begin{tabular}{|c|c|c|c|c|c|c|}
\hline \multirow[t]{2}{*}{ Country } & \multicolumn{2}{|c|}{ Women's change } & \multicolumn{2}{|c|}{ Men's change } & \multicolumn{2}{|c|}{$\Delta$ Women's $-\Delta$ Men's } \\
\hline & Period 1 & Period 2 & Period 1 & Period 2 & Period 1 & Period 2 \\
\hline \multicolumn{7}{|c|}{ Czech Republic $(1989,1996,2002)^{\mathrm{a}}$} \\
\hline Year of education & $0.032^{*}$ & -0.003 & $0.031^{*}$ & -0.002 & 0.001 & -0.001 \\
\hline Apprentices (2-3 years) & $0.090^{*}$ & -0.032 & 0.035 & 0.083 & 0.055 & -0.115 \\
\hline Vocational h.s. (4 years) & $0.187^{*}$ & $-0.069^{*}$ & $0.169^{*}$ & 0.041 & 0.018 & -0.110 \\
\hline Academic h.s. (4 years) & $0.265^{*}$ & -0.009 & 0.215 & -0.044 & 0.050 & 0.035 \\
\hline University & $0.280^{*}$ & -0.035 & $0.259^{*}$ & 0.035 & 0.021 & -0.070 \\
\hline Czech Republic $(1984,1993)^{\mathrm{b}}$ & & & & & & \\
\hline $\begin{array}{l}\text { Year of education } \\
\text { Czech Republic }(1984,1992)^{\mathrm{c}}\end{array}$ & $0.016^{*}$ & & $0.028^{*}$ & & $-0.012^{*}$ & \\
\hline $\begin{array}{l}\text { Additional year of schooling } \\
\text { Estonia }(1989,1994)^{\mathrm{d}}\end{array}$ & $0.015^{\mathrm{N}}$ & & $0.022^{\mathrm{N}}$ & & $-0.007^{\mathrm{N}}$ & \\
\hline Elementary & 0.112 & & 0.101 & & 0.011 & \\
\hline Secondary & $0.187^{*}$ & & $0.145^{*}$ & & 0.042 & \\
\hline Special secondary & $0.307^{*}$ & & $0.227^{*}$ & & 0.080 & \\
\hline $\begin{array}{l}\text { University (4 years) } \\
\text { Hungary }(1986,1991)^{c}\end{array}$ & $0.502^{*}$ & & $0.487^{*}$ & & 0.015 & \\
\hline $\begin{array}{l}\text { Additional year of schooling } \\
\text { Hungary }(1986,1995,1998)^{\mathrm{e}}\end{array}$ & $0.027^{\mathrm{N}}$ & & $0.042^{\mathrm{N}}$ & & $-0.015^{\mathrm{N}}$ & \\
\hline Primary schooling & $-0.032^{*}$ & $0.128^{*}$ & -0.009 & $0.065^{*}$ & -0.023 & 0.063 \\
\hline Vocational & $-0.039^{*}$ & $0.133^{*}$ & 0.018 & $0.099^{*}$ & $-0.057^{*}$ & 0.034 \\
\hline Technical & $0.111^{*}$ & $0.158^{*}$ & $0.144^{*}$ & $0.129^{*}$ & -0.033 & 0.029 \\
\hline General & $0.135^{*}$ & $0.172^{*}$ & $0.184^{*}$ & $0.103^{*}$ & $-0.049^{*}$ & 0.069 \\
\hline College & $0.212^{*}$ & $0.116^{*}$ & $0.306^{*}$ & $0.193^{*}$ & $-0.094^{*}$ & $-0.077^{*}$ \\
\hline University & $0.279^{*}$ & $0.171^{*}$ & $0.352^{*}$ & $0.235^{*}$ & $-0.073^{*}$ & -0.064 \\
\hline Poland $(1986,1992)^{\mathrm{c}}$ & & & & & & \\
\hline $\begin{array}{l}\text { Additional year of schooling } \\
\text { Poland }(1994,2001)^{\mathrm{f}}\end{array}$ & $0.019^{\mathrm{N}}$ & & $0.013^{\mathrm{N}}$ & & $0.006^{\mathrm{N}}$ & \\
\hline Basic vocational & & -0.024 & & -0.007 & & -0.017 \\
\hline Secondary general & & $-0.048^{*}$ & & 0.039 & & -0.087 \\
\hline Secondary vocational & & $-0.056^{*}$ & & 0.032 & & $-0.088^{*}$ \\
\hline Post-secondary & & -0.046 & & $-0.090^{*}$ & & 0.044 \\
\hline $\begin{array}{l}\text { University } \\
\text { Russia }(1991,1994)^{\mathrm{c}}\end{array}$ & & $-0.064^{*}$ & & 0.010 & & -0.074 \\
\hline $\begin{array}{l}\text { Additional year of schooling } \\
\text { Slovakia }(1984,1993)^{\mathrm{b}}\end{array}$ & $0.049^{\mathrm{N}}$ & & $0.034^{\mathrm{N}}$ & & $0.015^{\mathrm{N}}$ & \\
\hline $\begin{array}{l}\text { Year of education } \\
\text { Slovak Republic }(1984,1992)^{\mathrm{c}}\end{array}$ & $0.010^{*}$ & & $0.021^{*}$ & & & \\
\hline $\begin{array}{l}\text { Additional year of schooling } \\
\text { Slovenia }(1987,1992)^{\mathrm{d}}\end{array}$ & $0.017^{\mathrm{N}}$ & & $0.025^{\mathrm{N}}$ & & $-0.008^{\mathrm{N}}$ & \\
\hline Elementary & $0.033^{*}$ & & $0.063^{*}$ & & -0.030 & \\
\hline Secondary & $0.095^{*}$ & & $0.087^{*}$ & & 0.008 & \\
\hline University ( 2 years) & $0.116^{*}$ & & $0.156^{*}$ & & -0.040 & \\
\hline $\begin{array}{l}\text { University (4 years) } \\
\text { Ukraine }(1991,1994)^{\mathrm{c}}\end{array}$ & $0.171^{*}$ & & $0.228^{*}$ & & -0.057 & \\
\hline Additional year of schooling & $0.036^{\mathrm{N}}$ & & $0.031^{\mathrm{N}}$ & & $0.005^{\mathrm{N}}$ & \\
\hline
\end{tabular}

Note: Appendix Tables A.2 and A.3 present the actual coefficients for each year.

* Significance at the $10 \%$ level. N Not able to test for significance. a Author's own estimation; b Chase (1998); c Brainerd (2000); d Orazem and Vodopivec (1997); e Joliffe and Campos (2005); $\mathrm{f}$ Adamchik and Bedi (2003). 
the differences in the estimated coefficients are so small that we infer at most limited economic significance. Only two studies contain results indicating a different evolution of returns over time for men and women. Chase (1998) finds such divergence in the Czech Republic between 1983 and 1993; Joliffe and Campos (2005) obtain a similar result for Hungary between 1986 and 1995. Both studies indicate that women lost ground relative to men in terms of their returns to education in the early part of the transition, although this finding applies only to people with vocational, general high school, and college and university education in Hungary. In general, women and men obtained similar increases in returns to education in the early transition and maintained their position in the later phase of the transition.

\section{Conclusion}

Using micro data from the end of the Communist period, the middle of the transition, and late in the transition for the Czech Republic, we find that markets provide considerably higher education-related returns than planners. However, markets maintain the same return to human capital gained from experience in the labor force. Although the gender-earnings gap was reduced in the Czech Republic over this period from 33\% in 1989 to $25 \%$ in 2002, this shrinkage can not be attributed to differences in the evolution of returns to education to men and women because we find these differences to be statistically insignificant. In addition, changes in the returns to education are similar for men and women in several other transition economies so that the market's valuation of human capital is not responsible for any changes in the gender-earnings gap in these countries either.

Remarkably, the major increase in the rate of return to education occurs in the first phase of the Czech transition, from 1989 to 1996, and no further change is found in the later phase, from 1996 to 2002. Data for Czech men confirm this pattern and earlier studies from other transition economies suggest that this phenomenon is widespread. Moreover, we find that the major restructuring of the pattern of employment by industry, by firm ownership, and by firm size also occurred in the first, rather than in the second phase, of the transition. Unlike the lengthy process of adjustment in capital markets and corporate governance that involved substantial structural changes into the late 1990s and early 2000s, the labor market appears to have adjusted to the change of regimes relatively quickly.

Our results indicate that the increase in returns to education is not due to differences in firm ownership, because the increase in the rate of return is similar in private and state sectors. Hence, returns to education are set by overall labor market competition rather than by firm ownership. Our estimates also contradict the hypothesis that education acquired under Communism is less appropriate for a market economy than education obtained during the transition. Either Communist education, which was always highly reputed internationally in areas such as mathematics and sciences, constitutes a good preparation for working in both economic systems or reforms in the educational system during the 1990s were limited in their impact on an individual's performance in the labor market. Finally, in both regimes, wages rise faster with extra years of education when the extra year conveys a certificate, i.e., the sheepskin effect. Hence, the shift to a market system is associated with a somewhat greater emphasis on completed education levels and degrees. In sum, markets pay women 
and men equally more for their human capital than did the planners; all the adjustment was made in the early part of the transition and it was driven by market forces rather than private ownership in the Czech Republic.

\section{Acknowledgments}

The authors thank Orley Ashenfelter, Stepan Jurajda, Jan Kmenta, an anonymous referee and the participants of the CERGE-EI Applied Microeconomics Seminar and the Comparative Economic Development Seminar at the University of Michigan for valuable comments. We are grateful to Ina Ganguli for excellent research assistance.

Appendix Table A.1

Means and standard deviation of variables for earnings regressions

\begin{tabular}{|c|c|c|c|c|c|c|}
\hline & \multicolumn{2}{|c|}{1989} & \multicolumn{2}{|c|}{1996} & \multicolumn{2}{|c|}{2002} \\
\hline & mean & std. dev. & mean & std. dev. & mean & std. dev. \\
\hline Women's log of earnings & 7.90 & 0.37 & 8.68 & 0.37 & 9.13 & 0.33 \\
\hline Men's log of earnings & 8.23 & 0.39 & 8.96 & 0.40 & 9.38 & 0.35 \\
\hline Experience (years) & 16.83 & 9.80 & 20.68 & 10.79 & 19.78 & 11.35 \\
\hline Experience $^{2}$ & 379.41 & 343.56 & 543.86 & 435.64 & 519.98 & 463.92 \\
\hline Education in years & 12.17 & 2.32 & 12.34 & 2.25 & 12.49 & 1.97 \\
\hline \multicolumn{7}{|l|}{ Level of education } \\
\hline Junior high school (reference) & 0.145 & 0.352 & 0.111 & 0.315 & 0.077 & 0.267 \\
\hline Apprentices w/2-3 years & 0.375 & 0.484 & 0.365 & 0.482 & 0.363 & 0.481 \\
\hline Vocational h.s. w/4 years & 0.338 & 0.473 & 0.365 & 0.482 & 0.387 & 0.487 \\
\hline Academic h.s. w/4 years & 0.058 & 0.234 & 0.060 & 0.238 & 0.087 & 0.283 \\
\hline University & 0.084 & 0.278 & 0.099 & 0.299 & 0.085 & 0.278 \\
\hline Other variables & & & 1.000 & & & \\
\hline Prague & 0.109 & 0.312 & 0.112 & 0.316 & 0.152 & 0.359 \\
\hline Child benefits included & 0.117 & 0.321 & 0.071 & 0.257 & - & - \\
\hline Gross earnings reported & 0.261 & 0.439 & 0.255 & 0.436 & - & - \\
\hline \multicolumn{7}{|l|}{ Industry } \\
\hline Agriculture & 0.071 & - & 0.040 & - & 0.030 & - \\
\hline Mining \& quarrying & 0.026 & 0.160 & 0.015 & 0.123 & 0.014 & 0.120 \\
\hline Construction & 0.026 & 0.158 & 0.025 & 0.155 & 0.019 & 0.137 \\
\hline Commerce (wholesale and retail) & 0.174 & 0.379 & 0.211 & 0.408 & 0.303 & 0.460 \\
\hline Manufacturing-Food, Textile, & 0.273 & 0.446 & 0.245 & 0.430 & 0.193 & 0.395 \\
\hline Manufacturing-machinery & 0.056 & 0.230 & 0.048 & 0.214 & 0.022 & 0.146 \\
\hline Finance, insurance, renting \& real estate & 0.017 & 0.130 & 0.052 & 0.221 & 0.038 & 0.191 \\
\hline Transport, telecommunications & 0.056 & 0.230 & 0.063 & 0.242 & 0.059 & 0.236 \\
\hline Public administration + education + health & 0.290 & 0.454 & 0.293 & 0.455 & 0.321 & 0.467 \\
\hline Unknown & 0.011 & 0.104 & 0.009 & 0.093 & 0.002 & 0.043 \\
\hline \multicolumn{7}{|l|}{ Ownership } \\
\hline Privatized (96) and large private (02) & - & - & 0.370 & 0.483 & 0.341 & 0.474 \\
\hline SOE \& Public administration & - & - & 0.251 & 0.434 & 0.292 & 0.455 \\
\hline De novo private (96) and small private (02) & - & - & 0.316 & 0.465 & 0.341 & 0.474 \\
\hline Other \& not known & - & - & 0.079 & 0.270 & 0.026 & 0.160 \\
\hline No. of obs. & \multicolumn{2}{|c|}{1642} & \multicolumn{2}{|c|}{1374} & \multicolumn{2}{|c|}{1104} \\
\hline
\end{tabular}


Appendix Table A.2

Men's returns to education

\begin{tabular}{|c|c|c|c|c|c|}
\hline \multirow[t]{2}{*}{ Country } & \multirow[t]{2}{*}{ Pre-transition } & \multirow[t]{2}{*}{ Early transition } & \multirow[t]{2}{*}{ Late transition } & \multicolumn{2}{|c|}{ Change } \\
\hline & & & & Period 1 & Period 2 \\
\hline \multicolumn{6}{|c|}{ Czech Republic $(1989,1996,2002)^{\mathrm{a}}$} \\
\hline Year of education & $\begin{array}{c}0.027 \\
(0.004)\end{array}$ & $\begin{array}{c}0.058 \\
(0.005)\end{array}$ & $\begin{array}{c}0.057 \\
(0.004)\end{array}$ & $0.031^{*}$ & -0.002 \\
\hline Apprentices (2-3 years) & $\begin{array}{c}0.077 \\
(0.037)\end{array}$ & $\begin{array}{c}0.112 \\
(0.049)\end{array}$ & $\begin{array}{c}0.195 \\
(0.035)\end{array}$ & 0.035 & 0.083 \\
\hline Vocational h.s. (4 years) & $\begin{array}{c}0.125 \\
(0.040)\end{array}$ & $\begin{array}{c}0.294 \\
(0.050)\end{array}$ & $\begin{array}{c}0.335 \\
(0.039)\end{array}$ & $0.169^{*}$ & 0.041 \\
\hline Academic h.s. (4 years) & $\begin{array}{c}0.136 \\
(0.084)\end{array}$ & $\begin{array}{c}0.351 \\
(0.107)\end{array}$ & $\begin{array}{c}0.307 \\
(0.065)\end{array}$ & 0.215 & -0.044 \\
\hline University & $\begin{array}{c}0.285 \\
(0.045)\end{array}$ & $\begin{array}{c}0.544 \\
(0.059)\end{array}$ & $\begin{array}{c}0.579 \\
(0.046)\end{array}$ & $0.259^{*}$ & 0.035 \\
\hline \multicolumn{6}{|l|}{ Czech Republic $(1984,1993)^{\mathrm{b}}$} \\
\hline Year of education & $\begin{array}{r}0.024 \\
(14.40)\end{array}$ & $\begin{array}{r}0.052 \\
(16.26)\end{array}$ & & $0.028^{*}$ & \\
\hline \multicolumn{6}{|l|}{ Czech Republic $(1984,1992)^{\mathrm{c}}$} \\
\hline \multicolumn{6}{|l|}{ Estonia $(1989, \Delta 1989-1994)^{\mathrm{d}}$} \\
\hline Elementary & $\begin{array}{r}0.096 \\
(1.68)\end{array}$ & & & $\begin{array}{r}0.101 \\
(1.31)\end{array}$ & \\
\hline Secondary & $\begin{array}{l}0.123 \\
(2.21)\end{array}$ & & & $\begin{array}{c}0.145 \\
(2.09)^{*}\end{array}$ & \\
\hline Special secondary & $\begin{array}{c}0.168 \\
(2.86)\end{array}$ & & & $\begin{array}{c}0.227 \\
(3.05)^{*}\end{array}$ & \\
\hline University (4 years) & $\begin{array}{l}0.208 \\
(3.39)\end{array}$ & & & $\begin{array}{c}0.487 \\
(6.28)^{*}\end{array}$ & \\
\hline \multicolumn{6}{|l|}{ Hungary $(1986,1991)^{\mathrm{c}}$} \\
\hline $\begin{array}{l}\text { Additional year of schooling } \\
\text { Hungary }(1986,1995,1998)^{\mathrm{e}}\end{array}$ & 0.044 & 0.086 & & $0.042^{\mathrm{N}}$ & \\
\hline Primary schooling & $\begin{array}{l}0.104 \\
(0.0023)\end{array}$ & $\begin{array}{c}0.095 \\
(0.0128)\end{array}$ & $\begin{array}{l}0.160 \\
(0.0186)\end{array}$ & -0.009 & $0.065^{*}$ \\
\hline Vocational & $\begin{array}{l}0.190 \\
(0.0023)\end{array}$ & $\begin{array}{c}0.208 \\
(0.0129)\end{array}$ & $\begin{array}{c}0.307 \\
(0.0189)\end{array}$ & 0.018 & $0.099^{*}$ \\
\hline Technical & $\begin{array}{c}0.317 \\
(0.0026)\end{array}$ & $\begin{array}{c}0.461 \\
(0.0134)\end{array}$ & $\begin{array}{c}0.590 \\
(0.0192)\end{array}$ & $0.144^{*}$ & $0.129^{*}$ \\
\hline General & $\begin{array}{c}0.238 \\
(0.0033)\end{array}$ & $\begin{array}{c}0.422 \\
(0.0148)\end{array}$ & $\begin{array}{c}0.525 \\
(0.0201)\end{array}$ & $0.184^{*}$ & $0.103^{*}$ \\
\hline College & $\begin{array}{c}0.516 \\
(0.0034)\end{array}$ & $\begin{array}{c}0.822 \\
(0.0145)\end{array}$ & $\begin{array}{c}1.015 \\
(0.0199)\end{array}$ & $0.306^{*}$ & $0.193^{*}$ \\
\hline University & $\begin{array}{c}0.690 \\
(0.0034)\end{array}$ & $\begin{array}{c}1.042 \\
(0.0147)\end{array}$ & $\begin{array}{c}1.277 \\
(0.0199)\end{array}$ & $0.352^{*}$ & $0.235^{*}$ \\
\hline Poland $(1986,1992)^{\mathrm{c}}$ & & & & & \\
\hline Additional year of schooling & 0.038 & 0.051 & & $\begin{array}{c}0.013^{\mathrm{N}} \\
\text { ntinued o }\end{array}$ & ext page) \\
\hline
\end{tabular}


Appendix Table A.2 (continued)

\begin{tabular}{|c|c|c|c|c|c|}
\hline \multirow[t]{2}{*}{ Country } & \multirow[t]{2}{*}{ Pre-transition } & \multirow[t]{2}{*}{ Early transition } & \multirow[t]{2}{*}{ Late transition } & \multicolumn{2}{|c|}{ Change } \\
\hline & & & & Period 1 & Period 2 \\
\hline \multicolumn{6}{|l|}{ Poland $(1994,2001)^{\mathrm{f}}$} \\
\hline \multirow[t]{2}{*}{ Basic vocational } & & 0.063 & 0.056 & & -0.007 \\
\hline & & $(0.011)$ & $(0.017)$ & & \\
\hline \multirow[t]{2}{*}{ Secondary general } & & 0.105 & 0.144 & & 0.039 \\
\hline & & $(0.022)$ & $(0.029)$ & & \\
\hline \multirow[t]{2}{*}{ Secondary vocational } & & 0.129 & 0.161 & & 0.032 \\
\hline & & $(0.013)$ & $(0.019)$ & & \\
\hline \multirow[t]{2}{*}{ Post-secondary } & & 0.203 & 0.113 & & $-0.090^{*}$ \\
\hline & & $(0.033)$ & $(0.040)$ & & \\
\hline \multirow[t]{2}{*}{ University } & & 0.422 & 0.432 & & 0.010 \\
\hline & & $(0.021)$ & $(0.031)$ & & \\
\hline \multicolumn{6}{|l|}{ Russia $(1991,1994)^{\mathrm{c}}$} \\
\hline Additional year of schooling & 0.028 & 0.062 & & $0.034^{\mathrm{N}}$ & \\
\hline \multicolumn{6}{|l|}{ Slovakia $(1984,1993)^{\mathrm{b}}$} \\
\hline \multirow[t]{2}{*}{ Year of education } & 0.028 & 0.049 & & $0.021^{*}$ & \\
\hline & $(13.21)$ & $(17.10)$ & & & \\
\hline \multicolumn{6}{|l|}{ Slovak Republic $(1984,1992)^{\mathrm{c}}$} \\
\hline Additional year of schooling & 0.036 & 0.061 & & $0.025^{\mathrm{N}}$ & \\
\hline \multicolumn{6}{|l|}{ Slovenia $(1987, \Delta 1987-1992)^{\mathrm{d}}$} \\
\hline \multirow[t]{2}{*}{ Elementary } & 0.044 & & & $0.063^{*}$ & \\
\hline & $(5.3)$ & & & $(3.6)$ & \\
\hline \multirow[t]{2}{*}{ Vocational } & 0.163 & & & $0.038^{*}$ & \\
\hline & $(23.5)$ & & & $(2.6)$ & \\
\hline \multirow[t]{2}{*}{ Secondary } & 0.319 & & & $0.087^{*}$ & \\
\hline & $(40.0)$ & & & $(5.2)$ & \\
\hline \multirow[t]{2}{*}{ University ( 2 years) } & 0.520 & & & $0.156^{*}$ & \\
\hline & $(43.3)$ & & & $(6.3)$ & \\
\hline \multirow[t]{2}{*}{ University (4 years) } & 0.715 & & & $0.228^{*}$ & \\
\hline & $(61.8)$ & & & $(9.8)$ & \\
\hline \multicolumn{6}{|l|}{ Ukraine $(1991,1994)^{\mathrm{c}}$} \\
\hline Additional year of schooling & 0.062 & 0.093 & & $0.031^{\mathrm{N}}$ & \\
\hline
\end{tabular}

Note: Standard errors are in parentheses for all but Estonia, Slovakia, and Slovenia, which have $t$-statistics.

* Significance at the $10 \%$ level.

$\mathrm{N}$ Not able to test for significance.

a Author's own estimation.

b Chase (1998).

c Brainerd (2000).

d Orazem and Vodopivec (1997).

e Joliffe and Campos (2005).

f Adamchik and Bedi (2003). 
Appendix Table A.3

Women's returns to education

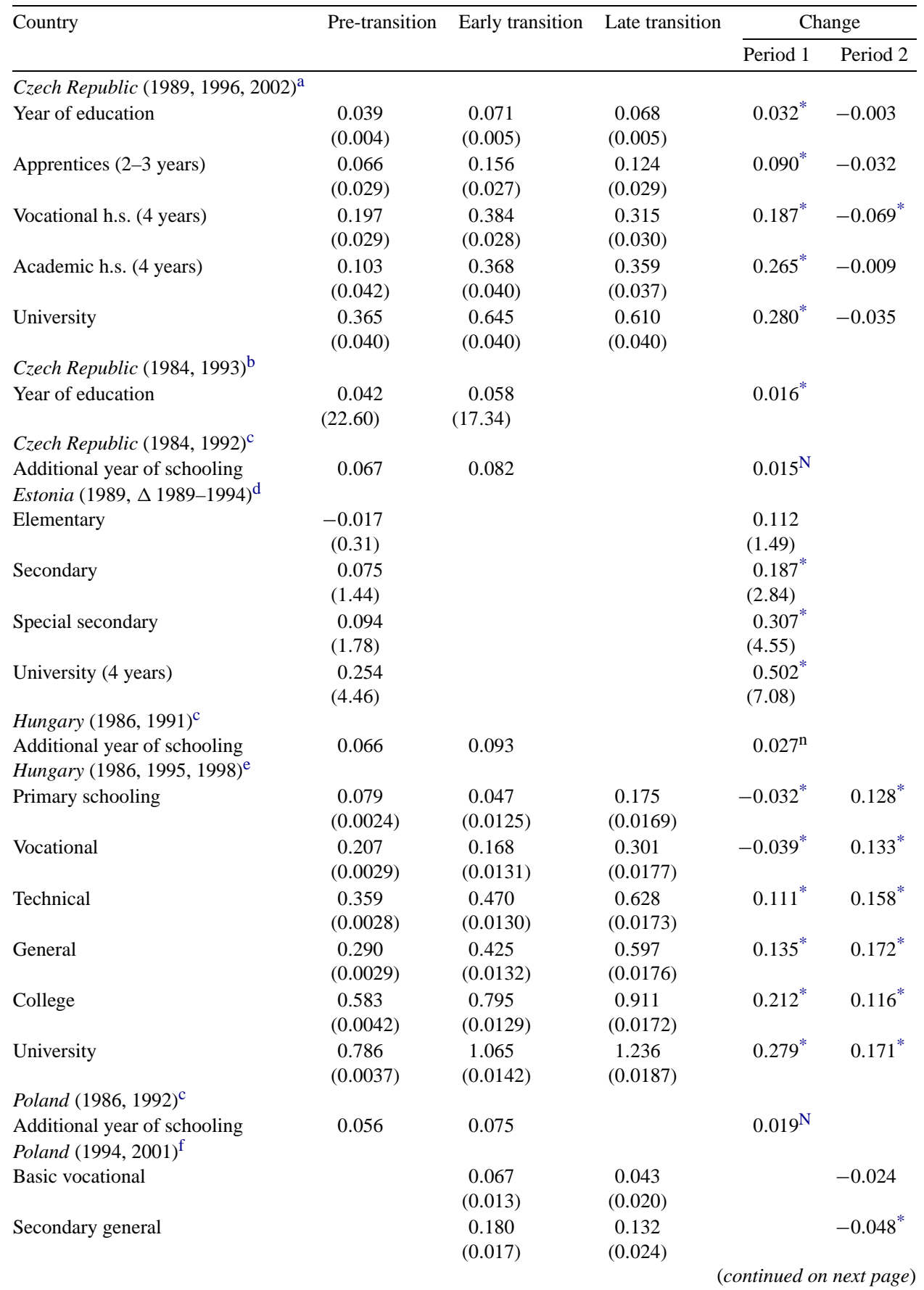


Appendix Table A.3 (continued)

\begin{tabular}{|c|c|c|c|c|c|}
\hline \multirow[t]{2}{*}{ Country } & \multirow[t]{2}{*}{ Pre-transition } & \multirow[t]{2}{*}{ Early transition } & \multirow[t]{2}{*}{ Late transition } & \multicolumn{2}{|c|}{ Change } \\
\hline & & & & Period 1 & Period 2 \\
\hline Secondary vocational & & $\begin{array}{c}0.176 \\
(0.015)\end{array}$ & $\begin{array}{c}0.120 \\
(0.022)\end{array}$ & & $-0.056^{*}$ \\
\hline Post-secondary & & $\begin{array}{c}0.216 \\
(0.022)\end{array}$ & $\begin{array}{c}0.170 \\
(0.029)\end{array}$ & & -0.046 \\
\hline University & & $\begin{array}{c}0.455 \\
(0.022)\end{array}$ & $\begin{array}{c}0.391 \\
(0.031)\end{array}$ & & $-0.064^{*}$ \\
\hline Russia $(1991,1994)^{\mathrm{c}}$ & & & & & \\
\hline $\begin{array}{l}\text { Additional year of schooling } \\
\text { Slovakia }(1984,1993)^{\mathrm{b}}\end{array}$ & 0.049 & 0.098 & & $0.049^{\mathrm{N}}$ & \\
\hline Year of education & $\begin{array}{r}0.044 \\
(17.56)\end{array}$ & $\begin{array}{r}0.054 \\
(18.20)\end{array}$ & & $0.010^{*}$ & \\
\hline Slovak Republic $(1984,1992)^{\mathrm{c}}$ & & & & & \\
\hline $\begin{array}{l}\text { Additional year of schooling } \\
\text { Slovenia }(1987, \Delta 1987-1992)^{\mathrm{d}}\end{array}$ & 0.073 & 0.090 & & $0.017^{\mathrm{N}}$ & \\
\hline Elementary & $\begin{array}{l}0.079 \\
(10.1)\end{array}$ & & & $\begin{array}{l}0.033^{*} \\
(1.87)\end{array}$ & \\
\hline Vocational & $\begin{array}{l}0.164 \\
(19.9)\end{array}$ & & & $\begin{array}{l}0.018 \\
(0.98)\end{array}$ & \\
\hline Secondary & $\begin{array}{l}0.370 \\
(44.9)\end{array}$ & & & $\begin{array}{c}0.095 \\
(5.16)^{*}\end{array}$ & \\
\hline University ( 2 years) & $\begin{array}{l}0.569 \\
(50.9)\end{array}$ & & & $\begin{array}{c}0.116 \\
(4.80)^{*}\end{array}$ & \\
\hline University (4 years) & $\begin{array}{l}0.768 \\
(59.3)\end{array}$ & & & $\begin{array}{c}0.171 \\
(6.26)^{*}\end{array}$ & \\
\hline Ukraine $(1991,1994)^{\mathrm{c}}$ & & & & & \\
\hline Additional year of schooling & 0.066 & 0.102 & & $0.036^{\mathrm{N}}$ & \\
\hline
\end{tabular}

Notes: Standard errors are in parentheses for all but Estonia, Slovakia, and Slovenia, which have $t$-statistics.

* Significance at the $10 \%$ level.

$\mathrm{N}$ Not able to test for significance.

a Author's own estimation.

b Chase (1998).

c Brainerd (2000).

d Orazem and Vodopivec (1997).

e Joliffe and Campos (2005).

f Adamchik and Bedi (2003).

\section{References}

Adamchik, Vera A., Bedi, Arjun S., 2003. Gender pay differentials during the transition in Poland. Economics of Transition 11, 697-726.

Brainerd, Elizabeth, 2000. Women in transition: Changes in gender wage differentials in Eastern Europe and the Former Soviet Union. Industrial and Labor Relations Review 54, 138-162.

Card, David, Krueger, Alan B., 1992. Does school quality matter? Returns to education and the characteristics of public schools in the United States. Journal of Political Economy 100, 1-40.

Chase, Robert S., 1998. Markets for communist human capital: Returns to education and experience in postcommunist Czech Republic and Slovakia. Industrial and Labor Relations Review 51, 401-423.

Czech Statistical Office, 1996. Labor Force Survey.

Czech Statistical Office, 2002. Microcensus. 
Flanagan, Robert J., 1998. Were communists good human capitalists? The case of the Czech Republic. Labour Economics 5, 295-312.

Heckman, James, 1974. Sample selection bias as a specification error. Econometrica 47, 153-161.

Heckman, James, Layne-Farrar, Anne, Todd, Petra, 1996. Does Measured School Quality Really Matter? An Examination of the Earnings-Quality Relationship. Brookings Institution Press, Washington, DC.

Hungerford, Thomas, Solon, Gary, 1987. Sheepskin effects in the returns to education. Review of Economics and Statistics 69, 175-177.

Hunt, Jennifer, 2002. The transition in East Germany: When is a ten-point fall in the gender wage gap bad news? Journal of Labor Economics 20, 148-169.

Jaeger, Dieter A., Page, Marianne E., 1996. Degrees matter: New evidence on sheepskin effects in the returns to education. Review of Economics and Statistics 78, 733-740.

Joliffe, Dean, 2002. The gender wage gap in Bulgaria: A semiparametric estimation of discrimination. Journal of Comparative Economics 30, 276-295.

Joliffe, Dean, Campos, Nauro F., 2005. Does market liberalization reduce gender discrimination? Econometric evidence from Hungary, 1986-1998. Labour Economics 12, 1-22.

Jurajda, Stepan, 2003. Gender wage gap and segregation in enterprises and the public sector in late transition countries. Journal of Comparative Economics 31, 199-222.

Krueger, Alan B., Pischke, Jorn-Steffen, 1995. A comparative analysis of East and West German labor markets: Before and after unification. In: Freeman, Richard B., Katz, Lawrence F. (Eds.), Differences and Changes in Wage Structures. Univ. of Chicago Press, Chicago, IL, pp. 405-446.

Layard, Richard, Psacharopoulos, George, 1974. The screening hypothesis and the returns to education. Journal of Political Economy 82, 985-998.

MEDIAN, 2003. Retrospective labour force inquiry II: Research report. Prague, Czech Republic.

Münich, Daniel, Svejnar, Jan, Terrell, Katherine, 1997. Final report to the Czech Ministry of Labor and Social Affairs on the retrospective questionnaire on employment histories. Unpublished.

Münich, Daniel, Svejnar, Jan, Terrell, Katherine, 2005. Returns to human capital under the communist wage grid and during the transition to a market economy. Review of Economics and Statistics 87, 100-123.

Nawata, Kazumitsu, 1993. A note on the estimation of models with sample selection biases. Economics Letters $42,15-24$.

Ogloblin, Constantin G., 1999. The gender earnings differential in the Russian transition economy. Industrial and Labor Relations Review 52, 602-627.

Orazem, Peter F., Vodopivec, Milan, 1997. The value of human capital in transition to market: Evidence from Slovenia, 1997. European Economic Review 41, 893-903.

Psacharopoulos, George, 1994. Returns to investment in education: A global update. World Development 22, 1325-1343.

Puhani, Patrick A., 2000. The Heckman correction for sample selection and its critique. Journal of Economic Surveys $14,53-68$. 